\title{
Restorative effect of Azadirachta indica against fenvalerate induced haematological and biochemical toxicity in a freshwater fish Clarias batrachus
}

\author{
Pratibha Kumari \\ Department of Zoology, Patna University, Patna (Bihar), India \\ Sanjay Kumar Jigyasu \\ Department of Zoology, Patna University, Patna (Bihar), India \\ Dilip Kumar Paul* \\ Department of Zoology, Patna University, Patna (Bihar), India \\ *Corresponding author. E-mail: dkpaul.pat31@gmail.com
}

\section{How to Cite}

Kumari, P. et al. (2020). Restorative effect of Azadirachta indica against fenvalerate induced haematological and biochemical toxicity in a freshwater fish Clarias batrachus. Journal of Applied and Natural Science, 12(4): 491-496. https://doi.org/10.31018/ jans.v12i4.2376

\begin{abstract}
Pesticide use in recent times has increased many folds to enhance the yield of crops. The water bodies like ponds and others are extensively used for the cultivation of fishes. Since these fishes are a good source of protein and nutritious value, hence are consumed by humans. These pesticide-contaminated fishes are consumed by the human, causing health hazards. The objective of the present research work was to know the bio remedial effect of Azadirachta indica on fenvalerate induced toxicity in a freshwater air-breathing catfish "Mangur" known as Clarias batrachus ( Linnaeus). The fishes were treated with $1 / 3^{\text {rd }}$ of LC 50 , i.e. $0.92 \mathrm{ppm}$ of a pyrethroid pesticide fenvalerate and observed the fishes for 96 hours. Thereafter, the aqueous leaf extract of Azadirachta indica was administered orally, daily by gastric intubation method at the dose of $100 \mathrm{mg} / \mathrm{Kg}$ body weight per day for 15 days. The study revealed that, after the exposure of $0.92 \mathrm{ppm}$ of fenvalerate, there was a significant decrease in RBC count from 2.76 to $2.14 \times\left(10^{6}\right)\left(\mathrm{mm}^{-3}\right)$, Total leukocyte count from18.10 to $16.30 \times\left(10^{3}\right)\left(\mathrm{mm}^{-3}\right)$, , packed ell volume from $24 \%$ to $16 \%$, haemoglobin from $6.89 \mathrm{~g} / 100 \mathrm{ml}$ to $4.23 \mathrm{~g} / 100 \mathrm{ml}$ of blood whereas increase in the level of serum glucose and cholesterol level from $50.33 \mathrm{mg} / \mathrm{dl}$ to $103.73 \mathrm{mg} / \mathrm{dl}$ and $168.52 \mathrm{~g} / \mathrm{dl}$ to $248.99 \mathrm{~g} / \mathrm{dl}$ respectively. At the same time, serum protein level decreased from $3.16 \mathrm{~g} / \mathrm{dl}$ to $2.52 \mathrm{~g} / \mathrm{dl}$ due to pesticide in the experimental fishes. But, after the administration of aqueous leaf extract of Azadirachta indica there was significant normalisation in the test parameters of the fishes. The study indicated that neem leaves possessed restorative effect against fenvalerate induced toxicity in Clarias batrachus.
\end{abstract}

Keywords: Fenvalerate, Azadirachta indica, Haematology, Biochemical assay, Clarias batrachus

\section{INTRODUCTION}

Bihar is the agriculturally based state, which is typically based on the cultivation of various types of Kharif and Rabi crops. For a better yield of crops, pesticides are widely used by the farmers. In recent times, fish farming in the state has attracted a lot of farmers. These fishes are cultivated near the agricultural land in the aquatic bodies. The aquatic bodies such as rivers, ponds also receive lots of agricultural runoff water which contains pesticides. These pesticides in higher concentrations are causing toxicity in the water fauna of the ponds, especially the fishes. Humans have been consuming these fishes due to its high nutritious value. The fishes through biomagnification of the pesticides are causing health hazards to humans. The organochlorine pesticides are more toxic than organophos- phates. Synthetic pyrethroids have been known as safe and environmentally friendly due to their mild toxicity to insects, mammals and birds, and they are reported highly toxic to a number of other non-target organisms especially aquatic organisms including fishes. Fenvalerate pesticide is capable of existing together in harmony with several other pesticide group and chemicals used to modify plant growth and plant micronutrients (Tomlin, 1995; Elbert et al., 2005; Bretschneider et al., 2007, Caglayan et al.,2016). It causes very least impact on the mammalians but possesses very high insecticidal activity.

Fenvalerate is a known neurotoxic pesticide which disrupts the sodium channels of neurons of insects followed by damaging the gamma-aminobutyric acid receptors and ATPase pathways (Narahasi, 1983; Cole et al., 1984; Clark and Matsumura, 1982; Matsu- 
mura, 1983; Eells et al., 1993). Indiscriminate use of fenvalerate pesticides in agricultural practices has resulted in accumulation in vital tissues of fishes (Coats et al., 1989; Mishra, 1996). The toxicological evaluation of fenvalerate has been carried out by various researchers (Lee et al., 1985; Tripathi, 1992; Tripathi and Verma, 2004; Jigyasu and Paul, 2016).

A new approach for the treatment of toxicity through medicinal plants has been very much popular in the recent times as they have proven a promising role to control the problem (Dutta-Mitra and Ahmed, 2015; Jha and Paul, 2020; Kumari and Paul, 2020). To enhance the fish immunity and to control the toxic effects of pesticides various medicinal plants have been widely used by the fish farmers (Vallejos et al., 2016; Awad and Awad, 2017; Nhu et al., 2020). All the parts of neem (Azadirachta indica), a member of the Meliaceae family is known as an excellent medicinal plant showing important role as health -promising effect due to its antioxidant source. Leaves mainly contain quercetin (flavonoid) and nimbosterol (ß- sitosterol) as well as a number of limonoids (nimbin and its derivatives). Quercetin (a polyphenolic flavonoid) is known to have antibacterial and antifungal properties. The principal constituents of neem leaves include protein $(7.1 \%)$, carbohydrates $(22.9 \%)$, minerals, calcium, phosphorus, vitamin $\mathrm{C}$, carotene etc. But they also contain glutamic acid, tyrosine, aspartic acid, alanine, praline, glutamine and cystine like amino acids, and several saturated and unsaturated fatty acids ) (Sujarwo et al., 2016; Gupta et al., 2017).

Neem is widely used for the treatment of skin manifestations, skin lesions, ulcers, urinary tract problems, gastrointestinal problems, diabetes etc. (Pandey et al., 1994; Subapriya and Nagini, 2005; Manikandan et al., 2008; Neem, 2012; Sharma et al., 2014).

The objective of the present investigation was to evaluate the toxic impact of fenvalerate, a commonly used insecticide, on haematological and biochemical parameters of a freshwater air-breathing fish Clarias batrachus and to find the restorative effect of medicinal plant, Azadirachta indica L. (neem) against fenvalerate induced toxicity.

\section{MATERIALS AND METHODS}

Live specimens of $C$. batrachus were procured from the local market of Patna, Bihar (India) and were acclimatized in the laboratory before experimentation. The proper condition was maintained for 15 days to acclimatize the fishes in aquaria. The fishes were fed with a mixture of egg and chopped wheat (flour) /suji with a very little amount of starch. The fishes were also fed with sliced goat liver every alternate day during midday. Utmost care was taken to keep the animals healthy and disease-free animals for the experiment. The experiments were done in the Post Graduate Department of Zoology, Patna University, Patna, Bihar, India. To conduct experiments, the ethical approval was given by Post Graduate Departmental Council of Zoology, Patna University, Patna, Bihar.

Fenvalerate $20 \%$ (Isagro-Asia, Gujarat, India) was procured from Patna market, and fishes were treated with it in the water contained in an aquarium at the dose of $1 / 3$ of $L_{50}$, i.e. 0.92 ppm and observed for 96 hrs.

To prepare an extract of leaves of neem were collected from the tree present in Patna Science College, Patna University and aqueous extract of neem leaves obtained using the method adopted by Neogi et al. (2007). LD 50 of leaf extract was estimated as $600 \mathrm{mg} /$ $\mathrm{Kg}$ body weight. The aqueous extract of neem at the dose of $100 \mathrm{mg} / \mathrm{Kg}$ body weight of the fish per day was given orally to the fenvalerate treated fishes daily.

A set of 10 fishes were considered as control group. The control group of fishes received no treatment. The second group of 10 fishes were treated with fenvalerate $(0.92 \mathrm{ppm})$ for 96 hours. The third aquarium fishes treated with fenvalerate insecticide were administered neem extract in the prerequisite dose, i.e. 100 $\mathrm{mg} / \mathrm{Kg}$ body weight of fishes per day orally for 15 days. The haematological indices such as red blood cell count, total white blood cell count, packed cell volume, haemoglobin percentage level and differential counts viz. eosinophil, lymphocytes and monocytes were estimated by the methods suggested by Darmady and Davenport (1954).

For the study of biochemical parameters, serum from the fish blood was extracted, and tests were carried out for the analysis of the total glucose levels, total protein levels and total cholesterol levels as per the methods suggested by Godkar and Godkar (2006).

Statistical evaluation of the results was done by adopting one-way ANOVA and Dunnett's test. Results are shown as mean and standard deviation.

\section{RESULTS AND DISCUSSION}

In the fenvalerate treated fishes the decreased value of haematological indices such as RBC counts ( $x$ $\left.10^{6} \mathrm{~mm}^{-3}\right)$, TLC counts $\left(x 10^{6} \mathrm{~mm}^{-3}\right)$, differential counts $\left(\times 10^{6} \mathrm{~mm}^{-3}\right)$, packed cell volume $(\%)$, haemoglobin (g/100 ml), eosinophils (\%) and monocyte levels(\%) whereas increase level was observed in lymphocytes (\%) after the fenvalerate exposer to the fishes. The restorative effect in haematological parameters was seen when the fishes were fed with the neem leaf extract for two weeks (Table 1).

During the biochemical study of fishes Increased level of serum glucose and serum cholesterol of fishes was observed whereas serum protein level showed increased manner due to fenvalerate treatment in comparison to control fishes. Again, there was an ameliorating effect in the altered values of biochemical indices after the treatment of neem extract for 15 days (Table 2).

The pesticides have caused serious health hazards to aquatic life. The biomagnification of the pesticides 
Kumari, P. et al. / J. Appl. \& Nat. Sci. 12(4): 491-496 (2020)

Table 1. Mean value of Hematological parameters of $C$. batrachus exposed to sublethal concentration of fenvalerate $(0.92 \mathrm{ppm})$ for 96 hours and neem extract for 15 days.

\begin{tabular}{llll}
\hline Parameter & Control & $\begin{array}{l}\text { Fenvalerate treated } \\
\text { for 96 hours }\end{array}$ & $\begin{array}{l}\text { Neem treated for } \\
\text { 15 days }\end{array}$ \\
\hline RBC $\left(\times 10^{6} \mathrm{~mm}^{-3}\right)$ & $2.76 \pm 0.032$ & $2.14 \pm 0.023$ & $2.59 \pm 0.154$ \\
Total Leukocyte Count $\left(\times 10^{3} \mathrm{~m}^{-3}\right)$ & $18.10 \pm 0.015$ & $16.30 \pm 0.074$ & $17.60 \pm 0.126$ \\
Differential Count $\left(\times 10^{6} \mathrm{~mm}^{-3}\right)$ & $12 \pm 0.230$ & $09 \pm 0.083$ & $11 \pm 0.073$ \\
Packed Cell Volume (\%) & $24 \pm 0.189$ & $16 \pm 0.041$ & $22 \pm 0.290$ \\
Haemoglobin $(\mathrm{g} / 100 \mathrm{ml})$ & $6.89 \pm 0.031$ & $4.23 \pm 0.073$ & $5.20 \pm 0.189$ \\
Eosinophils (\%) & $78 \pm 0.027$ & $64 \pm 0.061$ & $74 \pm 0.470$ \\
Lymphocytes (\%) & $10 \pm 0.152$ & $16 \pm 0.091$ & $12 \pm 0.241$ \\
Monocytes $(\%)$ & $01 \pm 0.039$ & Zero & $0.4 \pm 0.056$ \\
\hline
\end{tabular}

Table 2. Mean values of biochemical parameters of $C$. batrachus exposed to sublethal concentration of fenvalerate (0.92 ppm) for 96 hours and neem extract for 15 days.

\begin{tabular}{llll}
\hline Parameter & Control & $\begin{array}{l}\text { Fenvalerate treated for } \\
\mathbf{9 6} \text { hours }\end{array}$ & $\begin{array}{l}\text { Neem treatment for } \\
\text { 15 days }\end{array}$ \\
\hline Serum Glucose $(\mathrm{mg} / \mathrm{dl})$ & $50.33 \pm 0.103$ & $103.73 \pm 0.208$ & $59.98 \pm 0.173$ \\
Serum Cholesterol $(\mathrm{g} / \mathrm{dl})$ & $168.52 \pm 0.319$ & $248.99 \pm 0.394$ & $203.73 \pm 0.301$ \\
Seru Protein $(\mathrm{g} / \mathrm{dl})$ & $3.16 \pm 0.009$ & $2.52 \pm 0.006$ & $2.89 \pm 0.007$ \\
\hline
\end{tabular}

through the food chain reaches humans. This leads to the entry of pesticidal toxicity to the vital organs of the human body leading to cause disease in them (Katagi, 2010; Clasen et al., 2018; Yang et al., 2020; Mojiri et al., 2020). The pollution in the aquatic fauna can be observed in the fishes as they are the best indicators. Hence their haematological parameters can be used for the toxicity evaluation (Sharma and Singh, 2004 and 2006; Ramesh et al., 2014; Woo et al., 2018; Bojarski and Witeska, 2020).

In the present haematological study, there was a significant decrease in the RBC counts, TLC counts, Differential counts, Haemoglobin percentage, PCV percentage, Eosinophils and Monocytes percentage after fenvalerate exposure while after neem extract treatment there was a significant decrease in their levels. There was a significant increase in the Lymphocyte percentage after Fenvalerate exposure, but in neem leaf extract-treated group, there was a significant decrease in their levels.

Fenvalerate has caused significant damage on C.batrachus on the haematological parameters. The significant decrease (from $2.76 \pm 0.032 \times 10^{6} \mathrm{~mm}^{-3}$ to $2.14 \pm 0.023 \times 10^{6} \mathrm{~mm}^{-3}$ ) in RBC indicated that erythropoietic stem cell damage due to fenvalerate, while decrease in the total leukocyte counts (from $18.10 \pm 0.015 \times 10^{6} \mathrm{~mm}^{-3}$ to $16.30 \pm 0.074 \times 10^{6} \mathrm{~mm}^{-}$ ${ }^{3}$ ) was due to myelosuppression. Ultimately it caused low immunity and anaemia in the pesticide-treated fish (Narra, 2016; Narra et al., 2017; Abd El-Rahman et al., 2019). Furthermore, the increased value of lymphocytes denoted the obvious defence breach in the fish body (Gul et al., 2012).

During experimentation, there was increased value in serum glucose levels from $50.33 \mathrm{mg} / \mathrm{dl}$ to $103.73 \mathrm{mg} /$ $\mathrm{dl}$ and serum cholesterol value from $168.52 \mathrm{~g} / \mathrm{dl}$ to $248.99 \mathrm{~g} / \mathrm{dl}$ while decrease value in the serum protein from $3.16 \mathrm{~g} / \mathrm{dl}$ to $2.52 \mathrm{~g} / \mathrm{dl}$ in biochemical parameters of fishes due to exposer with fenvalerate. The fats are stored in the form of cholesterol and glucose in the form of glycogen in the liver. The hepatotoxicity caused due to fenvalerate has led to the change in biochemical parameters. Hence, change in the levels denotes the impact of toxicity. (Binukumari et al., 2016; Nejatkhah Manavi et al., 2018; Vieira and Dos Reis Martinez, 2018; Pico et al., 2019).

In the present study, the aqueous extract of neem leaves was used as an antidote against the fenvalerate induced toxicity in Clarias batrachus. There was a significant increase in the haematological parameters such as RBC counts, Total leucocyte counts, Differential counts, Packed cell volume percentage, haemoglobin percentage, Eosinophil percentage and Monocyte percentage while a decrease in the Lymphocyte percentage against fenvalerate induced toxicity. This denotes that the haematopoietic stem cells are significantly revived due to quercetin (flavonoid) and nimbosterol (ß- sitosterol), limbin and its derivatives which are active constituents of neem. The active ingredients quercetin, a flavonoid and nimbosterol (ß- sitosterol) play the vital role as antioxidant and immuno-booster. This enhances the defence mechanism of the fishes such as Channa punctatus Lates calcarifer, Pangasianodon hyphophthalmus. Moreover, they are also helpful to eliminate the pesticide bioaccumulation from the fish body (Farah et al., 2006; Talpur and Ikwanuddin, 2013; Nhu et al., $2019^{a}$ ).

In the present study, neem leaf extract played a vital role to control the fenvalerate induced toxicity in $C$. 
batrachus. The normalisation of haematological and biochemical parameters of the fishes at much extent denotes the active function of the quercetin and nimbosterol particularly against pathogen Aeromonas hydrophila in goldfish , zebrafish (Danio rerio). (Harikrishnan and Balasundaram, 2008; Batista et al., 2018; Kapinga et al., 2018; Nhu et al., 2019 ${ }^{\mathrm{b}}$ ). Hence, Neem extracts can be used as an antidote against fenvalerate induced toxicity in C. batrachus.

\section{Conclusion}

Fenvalerate caused a deleterious effect on the fishes at the haematological and biochemical level such as RBCs, total leucocytes, haemoglobin, serum glucose, serum cholesterol, serum protein in the indigenous fish C. batrachus, common food item of the people. A. indica ( neem) played a vital role to control the fenvalerate induced toxicity. Hence, it possessed the restorative activity in fenvalerate induced toxicity. The aquatic extract of the different parts of neem trees, easily available in India, may be used for therapeutic uses of several diseases of the fishes caused due to common pollutant pesticides in the aquatic bodies.

\section{ACKNOWLEDGEMENTS}

The authors extend their highly obligation to the Head, Department of Zoology, Patna University, Patna for providing the laboratory facilities.

\section{Conflict of interest}

The authors declare that they have no conflict of interest.

\section{REFERENCES}

1. Abd El-Rahman, G.I., Ahmed, S.A.A., Khalil, A.A., and Abd-Elhakim, Y.M. (2019). Assessment of hematological, hepato-renal, antioxidant, and hormonal responses of Clarias gariepinus exposed to sub-lethal concentrations of oxyfluorfen. Aquatic Toxicology, 217: 105329. https:// doi.org/10.1016/j.aquatox.2019.105329.

2. Awad, E., and Awaad, A. (2017). Role of medicinal plants on growth performance and immune status in fish. Fish Shellfish Immunol, 67: 40 54 . https://doi.org/10.1016/ j.fsi.2017.05.034.

3. Batista, F. L. A., Lima, L. M., Abrante, I. A., de Araújo, J. I. F., Batista, F. L. A., Abrante, I. A., ... Moura, L. F. (2018). Antinociceptive activity of ethanolic extract of Azadirachta indica A. Juss (Neem, Meliaceae) fruit through opioid, glutamatergic and acid-sensitive ion pathways in adult, zebrafish (Danio rerio). Biomedicine \& Pharmacotherapy, 108: 408-416. https://doi.org/10.1016/j.biopha.2018.0 8.160.

4. Binukumari, S., Devi, K. A., and Vasanthi, J. (2016). Applications in environmental risk assessment of biochemical analysis on the Indian fresh water fish, Labeo rohita exposed to monocrotophos pesticide. Environmental Toxicology and Pharmacology, 47: 200-205. https:// doi.org/10.1016/j.etap.2016.08.014.

5. Bojarski, B., and Witeska, M. (2020). Blood biomarkers of herbicide, insecticide, and fungicide toxicity to fish-a review. Environmental Science and Pollution Research, 1-
15. https://doi.org/10.1007/s11356-020-08248-8.

6. Bretschneider, T., Fischer, R., and Nauen, R. (2007). Inhibitors of lipid synthesis (acetyl-CoA-carboxylase inhibitors). Modern Crop Protection Compounds, 3: 909-926.

7. Caglayan, A., Kocer-Gumusel, B., Erkekoglu, P. and Hincal, F.( 2016). The effects of fenvalerate on hepatic and cerebral xenobiotic metabolizing enzymes in selenium and/or iodine deficient rats. Iranian Journal of Basic Medical Sciences, 19(10): 1040-1048.

8. Clark, J. M., and Matsumura, F. (1982). Two different types of inhibitory effects of pyrethroids on nerve Ca-and $\mathrm{Ca}+\mathrm{Mg}-\mathrm{ATP}$ ase activity in the squid, Loligo pealei. Pesticide Biochemistry and Physiology, 18(2): 180-190.

9. Clasen, B., Loro, V. L., Murussi, C. R., Tiecher, T. L., Moraes, B., and Zanella, R. (2018). Bioaccumulation and oxidative stress caused by pesticides in Cyprinus carpio reared in a rice-fish system. Science of the Total Environment, 626: 737-743. https://doi.org/10.1016/j.scitotenv.20 18.01.154.

10.Coats, J. R., Symonik, D. M., Bradbury, S. P., Dyer, S. D., Timson, L. K., and Atchison, G. J. (1989). Toxicology of synthetic pyrethroids in aquatic organisms: An overview. Environmental Toxicology and Chemistry: An International Journal, 8(8): 671-679.

11.Cole, L. M., Lawrence, L. J., and Casida, J. E. (1984). Similar properties of [35S] t-butylbicyclophosphorothio nate receptor and coupled components of the GABA receptor-ionophore complex in brains of human, cow, rat, chicken and fish. Life sciences, 35 (17):1755-176 2. https:// doi.org/10.1016/0024-3205(84)90272-8.

12.Datta-Mitra, A., and Ahmed Jr, O. (2015). Ayurvedic medicine use and lead poisoning in a child: A continued concern in the United States. Clinical Pediatrics, 54(7): 690692. https://doi.org/10.1177/0009922814553397.

13.Darmady , E.M. and Davenport, S.G.T. (1954). Haematological Technique for Medical Students. J. > Chuchill Ltd. London. pp 27-46.

14.Eells, J. T., Rasmussen, J. L., Bandettini, P. A., and PRoPP, J. M. (1993). Differences in the neuroexcitatory actions of pyrethroid insecticides and sodium channelspecific neurotoxins in rat and trout brain synaptosomes. Toxicology and Applied Pharmacology, 123(1): 107-119. https://doi.org/10.1006/taap.1993.1227.

15.Elbert, A., Brück, E., Melgarejo, J., Schnorbach, H. J., and Sone, S. (2005). Field development of Oberon ${ }^{\circledR}$ for whitefly and mite control in vegetables, cotton, corn, strawberries, ornamentals and tea. PflanzenschutzNachrichten Bayer, 58(3): 441-468.

16.Farah, M. A., Ateeq, B., \& Ahmad, W. (2006). Antimutagenic effect of neem leaves extract in freshwater fish, Channa punctatus evaluated by cytogenetic tests. Science of the Total Environment, 364(1-3): 200214. https://doi.org/10.1016/j.scitotenv.2005.07.008.

17.Godkar, S.L. and Godkar, D.P. (2006). Text Book of medical Laboratory Technology. $2^{\text {nd }}$ Edition. Bhalani Publishing House. Mumbai, India . pp 1024.

18.Gül, A., Benli, A. Ç. K., Ayhan, A., Memmi, B. K., Selvi, M., Sepici Dinçel, A. and Erkoç, F. (2012). Sublethal propoxur toxicity to juvenile common carp (Cyprinus carpio L., 1758): Biochemical, hematological, histopathological, and genotoxicity effects. Environmental Toxicology and Chemistry, 31(9): 2085-2092. https://doi.org/10.1002/ etc. 1924 .

19.Gupta, S. C., Prasad, S., Tyagi, A. K., Kunnumakkara, A. B., and Aggarwal, B. B. (2017). Neem (Azadirachta indi- 
ca): An Indian traditional panacea with modern molecular basis. Phytomedicine, 34: 14-20. https://doi.org/10.1016/ j.phymed.2017.07.001.

20.Harikrishnan, R., and Balasundaram, C. (2008). In vitro and in vivo studies of the use of some medicinal herbals against the pathogen Aeromonas hydrophila in goldfish. Journal of Aquatic Animal Health, 20(3): 165-176. https://doi.org/10.1577/H05-035.1.

21.Kapinga, I. B., Limbu, S. M., Madalla, N. A., Kimaro, W. H., and Tamatamah, R. A. (2018). Aspilia mossambicensis and Azadirachta indica medicinal leaf powders modulate physiological parameters of Nile tilapia (Oreochromis niloticus). International Journal Of Veterinary Science and Medicine, 6(1): 31-38. https://doi.org/10.1016/ j.ijvsm.2018.03.003.

22.Katagi, T. (2010). Bioconcentration, bioaccumulation, and metabolism of pesticides in aquatic organisms. In Reviews of Environmental Contamination and Toxicology (pp. 1132). Springer, New York, NY. https://doi.org/10.1007/978 -1-4419-1440-8_1.

23.Jha, S. K., and Paul, D. K. (2020). Efficacy of Withania somnifera on lipid profile of endosulfan induced toxicity in Swiss albino mice. Journal of Applied and Natural Science ,12(3): 454-459.

24.Jigyasu, S. K., and Paul, D. K. (2016). Renatosomatic index of a freshwater fish intoxicated with pyrethroid pesticide. Nature Environmental and Pollution Technology, 15 (3): 963-965.

25.Kumari, P. and Paul , D. K. ( 2020) . Ameliorating effect of Curcuma longa on bimodal oxygen uptake of a freshwater air breathing fish Clarias batrachus. World Journal of Pharmaceutical and Life Sciences, 6(8): 394-398.

26.Lee, P. W., Stearns, S. M., and Powell, W. R. (1985). Rat metabolism of fenvalerate (Pydrin insecticide). Journal of Agricultural and Food Chemistry, 33(5): 988-993.

27.Manikandan, P., Letchoumy, P. V., Gopalakrishnan, M., and Nagini, S. (2008). Evaluation of Azadirachta indica leaf fractions for in vitro antioxidant potential and in vivo modulation of biomarkers of chemoprevention in the hamster buccal pouch carcinogenesis model. Food and Chemical Toxicology, 46(7): 2332-2343. https://doi.org/10.1016/ j.fct.2008.03.013.

28.Matsumura, F. (1983). Influence of chlorinated and pyrethroid insecticides on cellular calcium regulatory mechanisms. In Mode of action, metabolism and toxicology (pp. 3-13). Pergamon.

29.Mishra, S., (1996). Bioaccumulation, biotoxicity and biodegradation of fenvalerate in rats ( $\mathrm{PhD}$ Thesis). University of Roorkee, India.

30.Mojiri, A., Zhou, J. L., Robinson, B., Ohashi, A., Ozaki, N., Kindaichi, T., ... Vakili, M. (2020). Pesticides in aquatic environments and their removal by adsorption methods. Chemosphere, 126646. https://doi.org/10.1016/ j.chemosphere.2020.126646.

31.Narahashi, T. (1983). Nerve membrane sodium channels as the major target site of pyrethroids and DDT. In Mode of Action, Metabolism and Toxicology (pp. 109-114). Pergamon.

32.Narra, M. R., Rajender, K., Reddy, R. R., Murty, U. S., and Begum, G. (2017). Insecticides induced stress response and recuperation in fish: biomarkers in blood and tissues related to oxidative damage. Chemosphere, 168: 350-357.https://doi.org/10.1016/j.chemosphere.2016.10.066.

33.Narra, M. R. (2016). Single and cartel effect of pesticides on biochemical and haematological status of Clarias ba- trachus: A long-term monitoring. Chemosphere, 144: 966974. https://doi.org/10.1016/j.chemosphere.2015.09.065.

34.Neem, U.N.E.P., 2012. The UN's tree of the 21st century. pp. Nairobi: United Nations Environment Programme. http://www.unep.org/wed/tree-a-day/neem.asp.

35.Nejatkhah Manavi, P., Shirvani Mahdavi, E., and Mazumder, A. (2018). Organochlorine pesticides in two fish species from the southern Caspian Sea. Marine pollution Bulletin, 133: 289-293. https://doi.org/10.1016/ j.marpolbul.2018.05.05

36.Neogi, U., ,Saumya , R., and Bushra I. (2007). In vitro combinational effect of bio active plant extracts on common food pathogen. Research Jr. of Microbiology.2(5):500 -503 .

37.Nhu, T. Q., Bich Hang, B. T., Cornet, V., Oger, M., Bach, L. T., Anh Dao, N. L., Thanh Huong, D. T., QuetinLeclercq, J., Scippo, M. L., Phuong, N. T., and Kestemont, P. (2020). Single or Combined Dietary Supply of Psidium guajava and Phyllanthus amarus Extracts Differentially Modulate Immune Responses and Liver Proteome in Striped Catfish (Pangasianodon hyphophthalmus). Frontiers in immunology, 11: 797. https:/l doi.org/10.3389/fimmu.2020.00797

38.Nhu, T. Q., Bich Hang, B. T., Vinikas, A., Bach, L. T., Buu Hue, B. T., Thanh Huong, D. T., Quetin-Leclercq, J., Scippo, M. L., Phuong, N. T., and Kestemont, P. $\left(2019^{\mathrm{a}}\right)$. Screening of immuno-modulatory potential of different herbal plant extracts using striped catfish (Pangasianodon hypophthalmus) leukocyte-based in vitro tests. Fish \& Shellfish Immunology, 93: 296-307. https:// doi.org/10.1016/j.fsi.2019.07.064.

39.Nhu, T. Q., Bich Hang, B. T., Bach, L. T., Buu Hue, B. T., Quetin-Leclercq, J., Scippo, M. L., Phuong, N. T., and Kestemont, P. $\left(2019^{b}\right)$. Plant extract-based diets differently modulate immune responses and resistance to bacterial infection in striped catfish (Pangasianodon hypophthalmus). Fish \& shellfish immunology, 92: 913-924. https:// doi.org/10.1016/j.fsi.2019.07.025.

40.Pandey, S. S., Jha, A. K., and Kaur, V. (1994). Aqueous extract of neem leaves in treatment of Psoriasis vulgaris. Indian Journal of Dermatology, Venereology, and Leprology, 60(2), 63

41.Pico, Y., Belenguer, V., Corcellas, C., Diaz-Cruz, M. S., Eljarrat, E., Farré, M., ... Barcelo, D. (2019). Contaminants of emerging concern in freshwater fish from four Spanish Rivers. The Science of the Total Environment, 659: 1186-1198. https://doi.org/10.1016/ j.scitotenv.2018.12.366.

42.Ramesh, M., Sankaran, M., Veera-Gowtham, V., and Poopal, R. K. (2014). Hematological, biochemical and enzymological responses in an Indian major carp Labeo rohita induced by sublethal concentration of waterborne selenite exposure. Chemico-biological interactions, 207: 67-73. https://doi.org/10.1016/j.cbi.2013.10.018.

43.Sharma, G., and Singh, S. (2006). Assay of some blood parameters of the fish, Channa punctatus (Bloch.) after intoxication of indofil. Bionotes, 8: 21.

44.Sharma, G., and Singh, S. (2004). Studies on the effect of intoxicant indofil on the blood morphology of Channa punctatus (Bloch.). Bionotes, 6(1): 20.

45.Sharma, C., Vas, A. J., Goala, P., Gheewala, T. M., Rizvi, T. A., and Hussain, A. (2014). Ethanolic Neem (Azadirachta indica) Leaf Extract Prevents Growth of MCF -7 and HeLa Cells and Potentiates the Therapeutic Index of Cisplatin. Journal of Oncology, 2014, 321754. https:// 
doi.org/10.1155/2014/321754.

46.Subapriya, R., and Nagini, S. (2005). Medicinal properties of neem leaves: a review. Current Medicinal Chemistry-Anti-Cancer Agents, 5(2): 149-156. https:// doi.org/10.21 74/1568011053174828.

47.Sujarwo, W., Keim, A. P., Caneva, G., Toniolo C. and Nicoletti, M. (2016). Ethnobotanical uses of neem (Azadirachta indica A.Juss.; Meliaceae) leaves in Bali (Indonesia) and the Indian subcontinent in relation with historical background and phytochemical properties. Journal of Ethnopharmacology, 189: 186-193. https:// doi.org/10.1016/j.jep.2016.05.014

48.Talpur, A. D., and Ikhwanuddin, M. (2013). Azadirachta indica (neem) leaf dietary effects on the immunity response and disease resistance of Asian seabass, Lates calcarifer challenged with Vibrio harveyi. Fish \& Shellfish Immunology, 34(1): 254-264. https://doi.org/10.1016/ j.fsi.2012.11.003.

49.Tomlin, C. (1995). The Pesticide Manual. Tenth Edition. Crop protection Publications. Bath Press, Bath. U.K. pp. 1341.

50.Tripathi, G., and Verma, P. (2004). Fenvalerate-induced changes in a catfish, Clarias batrachus: metabolic enzymes, RNA and protein. Comparative biochemistry and physiology. Toxicology \& Pharmacology: CBP, 138(1): 75 -79. https://doi.org/10.1016/j.cca.2004.05.005.
51.Tripathi G. (1992). Relative toxicity of aldrin, fenvalerate, captan and diazinon to the freshwater food-fish, Clarias batrachus. Biomedical and Environmental Sciences: BES, 5(1): 33-38.

52.Vallejos-Vidal, E., Reyes-López, F., Teles, M., and MacKenzie, S. (2016). The response of fish to immunostimulant diets. Fish \& Shellfish Immunology, 56: 34-69. https:// doi.org/10.1016/j.fsi.2016.06.028.

53. Vieira, C., and Dos Reis Martinez, C. B. (2018). The pyrethroid $\lambda$-cyhalothrin induces biochemical, genotoxic, and physiological alterations in the teleost Prochilodus lineatus. Chemosphere, 210, 958-967. https://doi.org/10.101 6/j.chemosphere.2018.07.115.

54.Woo, S. J., Kim, N. Y., Kim, S. H., Ahn, S. J., Seo, J. S. Jung, S. H., Cho, M. Y., and Chung, J. K. (2018). Toxicological effects of trichlorfon on hematological and biochemical parameters in Cyprinus carpio L. following thermal stress. Comparative biochemistry and physiology. Toxicology \& Pharmacology: CBP, 209: 18-27. https:// doi.org/10.1016/j.cbpc.2018.03.001.

55.Yang, C., Lim, W., and Song, G. (2020). Mediation of oxidative stress toxicity induced by pyrethroid pesticides in fish. Comparative Biochemistry and Physiology. Toxicology \& Pharmacology : CBP, 234: 108758. https:// doi.org/10.1016/j.cbpc.2020.108758. 